\title{
PERBANDINGAN MODEL PEMBELAJARAN MIND MAPPING BERBANTU LKS DENGAN METODE CERAMAH TERHADAP HASIL BELAJAR SISWA
}

\author{
Eric Dwi Putra', Lutfiyah' \\ 1,2Pendidikan Matematika IKIP PGRI Jember \\ dwieric454@gmail.com¹, azkalutfimh@gmail.com²
}

\begin{abstract}
Abtrak
Penelitian ini bertujuan untuk mengetahui perbedaan pada hasil belajar penerapan pembelajaran mind mapping dengan ceramah. Penelitian ini mengambil populasi pada Kelas VIII SMP N Terbuka 1 Gumukmas. Sampel di dalam penelitian diambil dengan cara acak yaitu kelas VIII TKA Al Aufa sebanyak 16 siswa di kelas dengan penerapan model pembelajaran mind mapping berbantuan LKS serta kelas VIII TKB Baiturrohman 14 siswa di kelas dengan metode ceramah. Pengumpulan data menggunakan metode tes. Teknik analisis data menggunakan analisis statistik deskriptif. Dari hasil penelitian serta analisis data bisa ditarik kesimpulan bahwa ada perbedaan terhadap hasil belajar kelas dengan penerapan model pembelajaran mind mapping berbantuan LKS dibandingkan kelas dengan metode ceramah. Hal ini dibuktikan dengan rerata nilai kelas dengan model pembelajaran mind mapping berbantuan LKS memperoleh 80,25 serta kelas dengan metode ceramah sebesar 68,85 .
\end{abstract}

Kata kunci: mind map, model ceramah, hasil belajar

\begin{abstract}
This study aims to show differences in the learning outcomes of applying mind mapping learning with lectures. This study took a population in Class VIII SMP N Open 1 Gumukmas. The sample in this study was taken randomly, namely class VIII TKA Al Aufa as many as 16 students in the class with mind mapping model with LKS and class VIII TKB Baiturrohman 14 students in the class with conventional method. Data collection used test method. Data analysis technique used descriptive statistical analysis. From the results of the research and data analysis, it can be concluded that there are differences in the learning outcomes of the class with mind mapping model with LKS compared to the class with conventional method. This is evidenced by the average value of the class with mind mapping model with LKS getting 80.25 and the class with conventional method of 68.85 .
\end{abstract}

Keywords: mind map, lecture model, learning outcomes

Prismatika: Jurnal Pendidikan dan Riset Matematika Vol. 2 No. 2 (2020) 
Eric Dwi Putra, Lutfiyah

Perbandingan Model Pembelajaran Mind Mapping Berbantu LKS dengan Model Ceramah terhadap Hasil Belajar Siswa

\section{PENDAHULUAN}

Pendidikan merupakan suatu kebutuhan untuk setiap anak. Pendidikan memiliki tujuan untuk mengembangkan sikap, pengetahuan, dan keterampilan pada diri seseorang sehingga ilmu yang diperoleh akan berguna untuk dirinya maupun sekitarnya. Hal utama didalam pendidikan yaitu kegiatan belajar mengajar didalam kelas. Proses belajar mengajar akan menentukan hasil belajar pada diri siswa. Belajar adalah aktivitas siswa yang bersifat kompleks sehingga menghasilkan perubahan sikap serta penambahan ilmu pengetahuan. Hal ini sesuai pendapat Morgan (Suprijono, 2009) yang menjelaskan bahwa Learning is any relatively permanent change in behavior that is a result of past experience. Proses belajar bisa dilaksanakan dengan berbagai model, metode serta media, tetapi tingkat penyerapan pada hasil belajar akan bervariasi tergantung tingkat kemampuan siswa didalam menyerap berbagai informasi baik yang disampaikan guru ataupun dari pengalaman nyata yang siswa lakukan.

Dalam proses pembelajaran matematika seharusnya lebih ditekankan dalam melakukan pemecahan masalah, dapat mengkomunikasikan berupa gagasan matematika terhadap berbagai konteks ilmu pengetahuan serta dapat mengembangkan proses berpikir maupun bernalar. Pembelajaran matematika merupakan kegiatan yang sangat komplek, artinya pembelajaran matematika itu akan dipengaruhi banyak faktor antara lain tujuan, materi, kompetensi, metode, bahan ajar, waktu, media, evaluasi, umpan balik, siswa serta guru. Jika komponen-komponen tersebut tidak dikelola ataupun diperhitungkan dengan sebaik-baiknya maka akan mengakibatkan lemahnya dari proses pembelajaran. Hal ini akan berdampak pada kurangnya pengembangan kemampuan siswa untuk berpikir kritis, logis serta penekanan proses pembelajaran terhadap pengembangan kemampuan siswa untuk mengingat serta menghafal materi yang telah diajarkan didalam proses pembelajaran.

Matematika merupakan mata pelajaran sangat penting didalam keberhasilan program pendidikan. Pelajaran matematika merupakan bagian dari pendidikan akademis serta ilmu dasar untuk disiplin ilmu yang lainnya, dan sekaligus sebagai sarana seorang siswa supaya mampu berpikir logis, kritis serta sistematis (Lestari, 2015). Ada beberapa tujuan dari pembelajaran matematika, diantaranya memecahkan masalah yang meliputi kemampuan pemecahan masalah, proses melakukan perancangan model matematika, 
selanjutnya proses dalam penyelesaian model, serta melakukan penafsiran solusi dari yang sudah didapatkan (Handayani, 2014).

Mengingat begitu pentingnya dari pelajaran matematika di sekolah, maka di dalam proses pelaksanaan di dalam kelas sangat diperlukan suatu kemampuan guru saat mengelola proses belajar mengajar di dalam kelas yang tujuannya diperoleh hasil belajar siswa bisa mencapai hasil optimal. Tetapi, kenyataan yang terjadi saat ini pembelajaran matematika lebih menekankan kepada bentuk hafalan materi serta guru kurang memberika fasilitas kepada siswa supaya memperoleh hasil belajar yang maksimal. Siswa sering dipaksa supaya mengingat berbagai rumus-rumus matematika tanpa dituntut dengan pemahaman dari siswa serta menemukan informasi berdasarkan potensi yang dimiliki. Sehingga siswa tidak memiliki konsep materi matematika yang akan dipelajari. Hal ini Senada dengan pendapat Putra (2019) yaitu saat proses pembelajaran matematika sering ditemukan siswa hanya melakukan proses menghafal rumus, hal tersebut terbukti ketika siswa mengerjakan serta menyelesaikan soal menggunakan rumus banyak siswa yang mengalami problem ataupun kesulitan. Hal ini menyebabkan siswa akan kesulitan jika menemukan soal berbeda dari contoh saat guru menjelaskan serta kepada siswa saat di dalam kelas akibatnya siswa menjadi bosan serta jenuh, ahirnya berakibat hasil belajar siswa kurang baik.

Permasalahan tersebut juga dijumpai dalam proses pembelajaran matematika berdasarkan wawancara kepada guru Matematika di SMP Negeri Terbuka 1 Gumukmas. Ketersediaan buku paket pelajaran matematika masih kurang mencukupi. Hal ini mengakibatkan masih terdapat siswa yang hanya mengandalkan informasi maupun materi ajar dari guru. Proses belajar mengajar yang berlangsung dalam kelas masih teacher centered. Berdasarkan hasil dari wawancara juga didapatkan informasi bahwa banyak siswa yang masih belum berpartisipasi saat didalam proses pembelajaran yang juga menjadi salah satu penghambat proses pembelajaran yang maksimal didalam kelas. Akhirnya berpengaruh terhadap prestasi belajar rendah yang diperoleh siswa. Rendahnya dari hasil belajar siswa bisa dilihat pada hasil nilai ujian ulangan harian materi matematika.

Rendahnya hasil belajar yang diperoleh siswa tentunya tidak akan terlepas dari beberapa faktor dan salah satunya faktor guru maupun faktor siswa tersebut, selain beberapa faktor lainnya. Guru masih menerapkan model 
pembelajaran konvensional yaitu ceramah. Dalam pelaksanaan belajar mengajar yang dilakukan guru masih sangat dominan serta siswa kurang dilibatkan dalam menggunakan beberapa permasalahan yang sesuai dalam kehidupan sehari-hari siswa saat proses belajar mengajar.

Secara garis besar, metode ceramah memiliki kelebihan di dalam proses kegiatan belajar mengajar yaitu guru bisa didalam waktu yang begitu singkat memberikan materi yang banyak kepada siswa serta dapat dimungkinkan guru bisa mengaitkan materi didalam kehidupan siswa sehari-hari. Sedangkan kekurangan untuk metode ceramah yaitu proses belajar mengajar hanya didominasi pengajar sementara siswa cenderung pasif serta cenderung hanya menghafal materi pelajaran sebagai fakta serta hanya bisa diingat sementara oleh siswa ahirnya siswa tidak akan terbantu mengorganisasikan materi didalam ingatan setiap siswa untuk jangka waktu panjang serta akan mengurangi kreavitas siswa (Rianto, 2006).

Dengan demikian, guru perlu adanya pemilihan model pembelajaran yang bisa mendidik siswa terlibat aktif di dalam kegiatan melakukan proses belajar mengajar. Pemilihan yang tepat dalam penentuan model pembelajaran oleh guru sangatlah penting saat proses mengajar di dalam kelas, dikarenakan model pembelajaran dapat membantu serta memudahkan siswa didalam memahami materi pelajaran. Salah satu solusi untuk dapat memaksimal hasil belajar matematika yaitu dengan menerapkan mind mapping.

Pembelajaran mind map memungkinkan dari siswa untuk mengeluarkan gagasan mereka serta membuat catatan kreatif dalam bentuk mind map. Hal tersebut di dukung pendapat Buzan (2009) yang mengatakan Mind map salah satu cara dalam mencatat yang efektif, kreatif, serta secara harfiah dapat melakukan pemetaan dari pikiran-pikiran. Dalam model ini akan menuntun siswa supaya memetakan pemikirannya terhadap materi yang dipelajari, sehingga akan mudah dipahami serta diingat oleh setiap siswa. Mind map yaitu peta rute begitu hebat untuk proses mengingat, maupun dapat memungkinkan dalam menyusun beberapa fakta serta pola pikiran yang ahirnya cara kerja yang dialami otak akan diikut sertakan secara awal (Buzan, 2005). Imaduddin dan Utomo (2012) menerangkan bahwa penggunaan Mind mapping dapat mendorong agar siswa bisa terbiasa membaca dengan sekilas tetapi secara keseluruhan selanjutnya mencari beberapa hal yang dirasa sanagat penting dengan cara menuliskan beberapa kata inti dari teks setelah siswa membaca, 
kemudian mereka akan mulai dengan terbiasa melengkapi dengan gambar maupun simbol dengan tujuan memudahkan siswa dalam memahami dari benda maupun keadaan-keadaan real.

Menurut De Porter dan Hernacki Mike (2011) mengatakan mind mapping mempunyai beberapa manfaat diantaranya: (1) fleksibel, disaat guru menyampaikan tentang teori maupun materi, siswa akan mudah menambahkan ditempat yang cocok didalam mind mapping siswa tanpa merasa bingung maupun kesulitan, (2) perhatian siswa dapat terpusat dikarenakan menerapkan mind mapping tidak butuh dalam menangkap setiap kata-kata yang dibrikan guru, siswa cukup memahami gagasan utama materi telah disajikan guru, (3) bisa meningkatkan pemahaman, serta (4) membuat siswa senang dikarenakan dengan pembelajaran Mind mapping dapat melakukan kombinasi antara kreativitas serta imajinasi siswa yang tidak memiliki batas, hal tersebut akan lebih membuat siswa senang jika dibandingkan harus membuat catatan atau rangkuman materi yang biasa. Keunggulan mind mapping tersebut dikombinasikan dengan bantuan LKS agar lebih mudah dipahami oleh siswa. Berbeda dengan penelitian sebelumnya dari Indriyani (2010) yang berfokus pada penerapan pembelajaran mind mapping sebagai upaya peningkatan pemahaman konsep. Berdasarkan pemaparan sebelumnya maka dilaksanakan penelitian dengan judul "Perbandingan Model Pembelajaran Mind mapping Berbantu LKS Dengan Model Ceramah Terhadap Hasil Belajar Siswa". Sedangkan tujuan panelitian ini yaitu untuk mengetahui adanya perbedaan pada hasil belajar antara penerapan model pebelajaran mind mapping dengan ceramah.

\section{METODE PENELITIAN}

Populasi di dalam penelitian adalah Kelas VIII SMP N Terbuka 1 Gumukmas. Sampel didalam penelitian diambil dengan cara acak yaitu kelas VIII TKA Al Aufa menjadi kelas eksperiment serta kelas VIII TKB Baiturrohman yang menjadi kelas kelas control. Instrumen pengambilan data di dalam penelitian yaitu tes hasil belajar matematika yang bertujuan untuk mengetahui hasil belajar siswa pada ranah kognitif serta lembar observasi berfungsi untuk melakukan observasi serta mengukur tingkat ketercapaian dari tujuan pembelajaran saat proses belajar mengajar. 
Prosedur pengambilan data didalam penelitian dilaksanakan dalam tiga tahap kegiatan. Tahap persiapan yang terdiri dari melakukan identifikasi masalah, menyusun laporan penelitian, menyusun Instrumen penelitian, meminta izin, dan memilih dua kelas dengan cara cluster random sampling, dengan pertimbangan siswa memperoleh materi yang sama. Tahap pelaksanaan yang dilakukan dengan beberapa langkah-langkah diantaranya mengambil data nilai ulangan materi sebelum penerapan pembelajaran, mengimplementasikan proses pembelajaran dengan menggunakan model pembelajaran mind mapping berbantuan LKS di satu kelas dan model konvensional (ceramah) di kelas lain, dan memberikan tes kepada untuk mengetahui hasil belajar siswa. Tahap penyelesaian terdiri dari mengumpulkan hasil data, pengolahan data, analisis data dari hasil penelitian, mengambil kesimpulan, dan menyususn laporan penelitian.

Teknik analisis data di dalam penelitian dengan analisis deskriptif terhadap hasil belajar siswa. Dari hasil proses perhitungan yang diperoleh tersebut kemudian dianalisis dengan pengkategorian penilaian hasil belajar siswa untuk kognitif.

Tabel 1 Indikator Penilaian Hasil Belajar

\begin{tabular}{cc}
\hline Hasil Belajar & Indikator \\
\hline $0-34$ & Sangat rendah \\
\hline $35-54$ & Rendah \\
\hline $55-64$ & Sedang \\
\hline $65-84$ & Tinggi \\
\hline $85-100$ & Sangat tinggi \\
\hline
\end{tabular}

\section{HASIL DAN PEMBAHASAN}

Dalam penelitian ini menggunakan 2 kelas dimana model pembelajaran mind mapping diterapkan di kelas VIII TKA Al Aufa dan metode ceramah di kelas VIII TKB Baiturrohman. Data tes akhir hasil belajar siswa pada materi matematika disajikan pada bentuk table distribusi frequensi.

\section{Hasil Belajar Matematika Kelas VIII TKA Al Aufa (Kelas Eksperiment) Setelah Dilaksanakan Model Mind mapping}

Tabel 2 berikut ini merupakan data distribusi frekuensi hasil belajar kelas dengan model pembelajaran mind mapping. 
Eric Dwi Putra, Lutfiyah

Perbandingan Model Pembelajaran Mind Mapping Berbantu LKS dengan Model Ceramah terhadap Hasil Belajar Siswa

Tabel 2 Distribusi Frequensi Hasil Belajar Matematika Kelas VIII TKA Al Aufa

\begin{tabular}{cc}
\hline Hasil Belajar & $\mathbf{F}_{\mathbf{i}}$ \\
\hline $60-64$ & - \\
\hline $65-69$ & 2 \\
\hline $70-74$ & - \\
\hline $75-79$ & 3 \\
\hline $80-84$ & 7 \\
\hline $85-89$ & 4 \\
\hline Jumlah & 16 \\
\hline
\end{tabular}

Data yang tersaji pada tabel 2 diatas, dijadikan acuan untuk proses pengolahan analisi deskriptif. Selanjutnya hasil analisis deskriptif yang tersaji pada tabel 2 terdapat pada tabel 3 berikut.

Tabel 3 Hasil Belajar Matematika Siswa Kelas VIII TKA Al Aufa

\begin{tabular}{cc}
\hline Parameter & Nilai \\
\hline Banyak peserta & 16 \\
\hline Nilai Maksimum & 88 \\
\hline Nilai Minimum & 68 \\
\hline Rata-rata & 80,25 \\
\hline Standar Deviasi & 5.551 \\
\hline Varians & 30,812 \\
\hline Koefisien Varian & $6,91 \%$ \\
\hline
\end{tabular}

Dari tabel 3 diatas, dijelaskan untuk nilai maksimum kelas ekperimen pada hasil belajar siswa materi matematika setelah dilaksanakan tes akhir yaitu memperoleh nilai 88. Sedangkan untuk nilai minimum yang diperoleh siswa yaitu 68. Hasil belajar bisa dikategorikan seperti tersaji pada Tabel 4. Tabel kategorisasi disajikan berikut ini.

Tabel 4 Kategorisasi Hasil Belajar Matematika Kelas VIII TKA Al Aufa

\begin{tabular}{cccc}
\hline Rentang Nilai & Frekuensi & Persentase (\%) & Indikator \\
\hline $0-34$ & 0 & 0 & Sangat rendah \\
\hline $35-54$ & 0 & 0 & Rendah \\
\hline $55-64$ & 0 & 0 & Sedang \\
\hline $65-84$ & 12 & 75 & Tinggi \\
\hline 85- 100 & 4 & 25 & Sangat tinggi \\
\hline jumlah & 16 & 100 & \\
\hline
\end{tabular}

Prismatika: Jurnal Pendidikan dan Riset Matematika Vol. 2 No. 2 (2020) 
Eric Dwi Putra, Lutfiyah

Perbandingan Model Pembelajaran Mind Mapping Berbantu LKS dengan Model Ceramah terhadap Hasil Belajar Siswa

Tabel 4 diatas menunjukkan pengkategorian dari kelas eksperimen diperoleh untuk hasil belajar matematika diketahui bahwa paling banyak yang diperoleh siswa yaitu berada pada nilai indikator tinggi sebanyak 12 siswa yang rentang nilainya 65-84. Sedangkan sebanyak 25 siswa berada pada indikator sangat tinggi.

\section{Hasil Belajar Matematika Kelas VIII TKB Baiturrohman (Kelas Kontrol) Setelah Dilaksanakan Model Ceramah}

Tabel 5 berikut ini merupakan data distribusi frekuensi hasil belajar kelas dengan metode ceramah.

Tabel 5 Distribusi Frequensi Hasil Belajar Matematika Kelas VIII TKB Baiturrohman

\begin{tabular}{cc}
\hline Hasil Belajar & $\mathbf{F}_{\mathbf{i}}$ \\
\hline $60-64$ & 4 \\
\hline $65-69$ & 5 \\
\hline $70-74$ & 2 \\
\hline $75-79$ & 1 \\
\hline $80-84$ & 2 \\
\hline $85-89$ & - \\
\hline Jumlah & 14 \\
\hline
\end{tabular}

Data yang tersaji pada tabel 5 diatas, menjadi acuan proses analisis deskriptif. Selanjutnya hasil dari analisis deskriptif yang tersaji pada table 5 terdapat pada table 6 dibawah berikut.

Tabel 6 Hasil Belajar Matematika Kelas VIII TKB Baiturrohman

\begin{tabular}{cc}
\hline Parameter & Nilai \\
\hline Banyak peserta & 14 \\
\hline Nilai Maksimum & 80 \\
\hline Nilai Minimum & 61 \\
\hline Rata-rata & 68,857 \\
\hline Standar Deviasi & 6,105 \\
\hline Varians & 37,265 \\
\hline Koefisien Varian & $8,86 \%$ \\
\hline
\end{tabular}

Dari tabel 6 diatas, dapat ditunjukkan untuk nilai tertinggi kelas kontrol pada hasil belajar siswa materi matematika setelah dilaksanakan tes akhir yaitu 
memperoleh nilai 80. Sedangkan untuk nilai minimum yang diperoleh siswa yaitu 61.

Berdasarkan tabel 6 diatas, juga diperoleh bahwa nilai koefisien varians sebesar 8,86 \%. Dari data yang diperoleh serta hasil dari analilsis deskriptif pada kelas kontrol dapat dikategorisikan pada tabel 7 dibawah berikut.

Tabel 7 Kategorisasi Hasil Belajar Matematika Kelas VIII TKB Baiturrohman

\begin{tabular}{cccc}
\hline Rentang Nilai & Frekuensi & Persentase (\%) & Indikator \\
\hline $0-34$ & 0 & 0 & Sangat rendah \\
\hline $35-54$ & 0 & 0 & Rendah \\
\hline $55-64$ & 4 & 28,5 & Sedang \\
\hline $65-84$ & 10 & 71,5 & Tinggi \\
\hline $85-100$ & 0 & 0 & Sangat tinggi \\
\hline jumlah & 14 & 100 & \\
\hline
\end{tabular}

Dari tabel 7 diperoleh informasi tentang sebaran dari skor hasil belajar matematika untuk siswa pada kelas kontrol. Ada 4 siswa yang berkategori sedang yang memiliki persentase 28,5\%. Sedangkan untuk kategori tinggi berjumlah 10 siswa yang memiliki peresentase 71,5 \%.

Berdasarkan tabel 3 dan tabel 6, pada kedua kelas dapat diperoleh untuk hasil belajar materi matematika dengan model pembelajaran mind mapping berbantuan LKS lebih baik daripada hasil belajar dengan metode ceramah. Hal tersebut bisa diamati dari rerata nilai pada kelas dengan model pembelajaran mind mapping berbantuan LKS memperoleh 80,25 serta kelas dengan metode ceramah sebesar 68,85. Selain hal tersebut berdasarkan tabel 4 dan tabel 7, pada kelas eksperimen dapat ditunjukkan bahwa perolehan kategori tinggi mencapai $75 \%$ siswa serta yang berkategori sangat tinggi mencapai 25\% tetapi untuk perolehan kategori sedang pada kelas kontrol hanya mencapai 28,5 \% siswa serta yang memperoleh kategori tinggi sebesar 71,5\%. Hal tersebut menunjukkan bahwa hasil belajar dengan model pembelajaran mind mapping berbantuan LKS lebih baik daripada hasil belajar dengan metode ceramah.

\section{Pembahasan}

Hasil penelitian yaitu untuk kelas VIII TKA Al Aufa yang dengan proses pembelajaran model mind mapping lebih tinggi daripada kelas VIII TKB Baiturrohman. Hal ini bisa diketahui berdasarkan rerata nilai siswa. 
Keberhasilan pelajaran matematika menggunakan pembelajaran mind mapping disebabkan langkah-langkah pembelajaran bisa membuat siswa menjadi senang karena mereka bisa membuat catatan kreatif sesuai dengan inspirasi yang dimiliki siswa, hal tersebut membuat siswa tidak jenuh, serta siswa menjadi lebih aktif. Ini sesuai dengan pendapat Aini, dkk (2012) bahwa mind mapping yaitu strategi didalam pembelajaran yang selalu melakukan usaha untuk mengaktifkan otak bagian kanan serta otak bagian kiri untuk bekerja seimbang. Aktivitas ini juga didukung oleh Buzan (2005) menjelaskan Mind map menjadi salah satu cara mencatat yang efektif, kreatif, serta mampu memetakan pikiran- pikiran.

Dari penjelasan diatas, pelaksanaan penggunaan mind map pada kelas VIII TKA Al Aufa, mempunyai kelebihan yaitu, saat proses kegiatan pembelajaran dapat menyenangkan, disebabkan saat proses pembelajaran didalam kelas siswa bisa membuat rangkuman pelajaran dengan konsep peta pikiran menggunakan spidol warna serta bentuk gambar sesuai imajinasi siswa sehingga banyak gambar mind mapping yang di hasilkan. Siswa memperoleh kesenangan banyak hal setelah membuat mind mapnya, memudahkan ketika dilihat, dibaca, dicerna, maupun di ingat. Selain itu juga lebih efisien serta efektif juga menjadi keunggulan yang didapatkan, dikarenakan guru sedikit berbicara, sehingga guru berfungsi hanya sebagai fasilitator. Selaras dengan pendapat Hobri (2009) bahwa keunggulan mind mapping yaitu bisa memfokuskan perhatian, dengan mind mapp siswa dapat berkonsentrasi pada gagasan inti sehingga tidak perlu memikirkan setiap penjelasan guru. Selain itu juga dalam pembelajaran mind mapiing dibantu dengan penggunaan LKS di dalam penerapan teorinya yang dilaksanakan saat proses pembelajaran dengan mind mapping akibatnya siswa lebih mudah saat proses belajarnya untuk tercapainya hasil dari belajar menjadi maksimal. Seperti pendapat Trianto (Arianti: 2015) bahwa LKS merupakan pedoman untuk melakukan penyelidikan ataupun pemecahan masalah.

Selanjutnya, kendala ataupun kekurangan saat proses pembelajaran yang dialami peneliti yaitu penyesuaian kepada siswa dalam kegiatan belajar. Disebabkan mind map merupakan metode baru didalam pembelajaran di kelas sehingga saat diawal kegiatan mind map sangat sulit diterapkan. Pada saat pembuatan mind mapping, masih banyak siswa yang kurang paham tata cara menyusun mind mapping, sehingga saat proses penyusunan, masih banyak yang 
bertanya. Hal ini selaras pernyataan Susanto (2011) yang mengatakan bahwa salah satu kelemahan mind mapping yaitu penggunaan mind mapping yang masih baru digunakan dalam pembelajaran mengakibatkan siswa kebingungan serta pengaplikasian model tidak akan maksimal apabila siswa tidak mampu ataupun kurang percaya diri terhadap kemampuan menggambar mereka.

Sedangkan saat di dalam proses pembelajaran menggunakan ceramah, siswa hanya diberikan pembelajaran sederhana berdasarkan buku paket yang dipegang oleh siswa dan guru, mendengarkan penjelasan guru, selanjutnya siswa diberikan beberapa soal yang ada didalam LKS, serta siswa diajak untuk menganalisis data serta menarik kesimpulan selanjunya dikuatkan guru. Langkah-langkah pembelajaran ceramah akan lebih berpusat terhadap guru tetapi tidak pada siswa. Saat guru memberikan masalah, pembelajaran ceramah hanya terfokus kepada guru akibatnya siswa sulit untuk memahami.

Saat proses pembelajaran di kelas VIII TKB Baiturrohman yang menggunakan metode ceramah siswa lebih diam serta hanya mengikuti penjelasan maupun penyampaian guru. Saat guru meminta siswa untuk bertanya saat ada materi yang belum dipahami, kelas menjadi hening karena siswa bingung tentang materi yang telah diberikan guru.

Langkah dalam ceramah yang digunakan tanpa kombinasi dengan model, metode, kegiatan, atau teknik yang lain menyebabkan siswa pasif akibatnya, kegiatan memberikan pertanyaan, tanggapan ataupun mmembuat catatan penalaran siswa terhadap materi tidak akan terjadi karena siswa merasa malu, takut, atau canggung selama proses pembelajaran dengan penerapan ceramah. Berdasarkan dari hasil penelitian yang telah dilaksanakan siswa lebih cenderung tertarik kepada masalah yang dikemukakan guru dengan urutan-urutan jelas, dibandingkan hanya dengan guru memberika penjelasan serta teori secara lisan, akibatnya hasil pembelajaran siswa di kelas ceramah tidak dapat mengungguli hasil belajar mind mapping pada kelas eksperimen.

Selain siswa menjadi pasif, siswa juga akan sulit mengembangkan materi yang ada didalam pikiran mereka karena siswa tidak memiliki konsep pada materi yang telah dipelajari. Siswa yang bersikap pasif pada VIII TKB Baiturrohman dalam kelas kontrol merupakan salah satu penyebab rendahnya/kurangnya hasil belajar siswa, karena mereka hanya diam, mendengarkan penjelasan guru serta tidak aktif bertanya jika ada materi mapun konsep yang belum dimengerti. Metode ceramah juga memiliki bebrapa 
kelebihan, diantaranya. Metode ceramah dapat menjadi lebih menyenangkan apabila proses pembelajaran dikombinasikan oleh guru dengan serta teknik pembelajaran model, serta metode yang lain, akibatnya guru tidak lagi menjadi pusat pembelajaran tetapi siswa juga dapat menjadi pusat pembelajaran sehingga siswa dapat aktif dan ahirnya dapat memahami konsep.

Berdasarkan dari beberapa analisis data serta pendapat-pendapat yang mendukung, bisa dinyatakan dinyatakan bahwa antara model pembelajaran dengan model mind mapping lebih efektif dibandingkan metode ceramah.

\section{KESIMPULAN DAN SARAN}

Berdasarkan dari hasil analisis data dan pembahasan yang telah dilakukan, maka bisa didapatkan kesimpulan bahwa terdapat adanya perbedaan terhadap hasil belajar anatara kelas eksperimen yang menerapkan model mind map serta kelas kontrol yang menggunakan ceramah. Untuk hasil belajar kelas eksperiment lebih baik daripada kelas kontrol. Hal ini dibuktikan dengan rerata nilai untuk nilai kelas eksperimen memperoleh 80,25 serta kelas kontrol sebesar 68,85 . Untuk penelitian selanjutnya dapat ditekankan pada penelitian tindakan kelas untuk meningkatkan hasil belajar atau kemampuan matematika lainnya dengan penerapan mind mapping.

\section{DAFTAR RUJUKAN}

Aini, A., Andayani \& Anindyarini, A. Metode Mind mapping Untuk Meningkatkan Kemampuan Berbicara Siswa Sekolah Dasar. (2012). BASASTRA Jurnal Penelitian Bahasa, Sastra Indonesia dan Pengajarannya, 1(1), 125-137.

Arianti, Dwi. (2015). Pengembangan Lembar Kerja Siswa (LKS) Materi Pecahan di Kelas IV Sekolah Dasar Menggunakan Strategi Tandur. Tesis tidak diterbitkan. Purwokerto: Universitas Muhammadiyah Purwokerto.

Buzan, T. (2005). Buku Pintar Mind Mapping. Jakarta: PT Gramedia Pustaka Utama.

Buzan, T. (2009). Buku Pintar Mind Map. Jakarta: PT. Gramedia Pustaka Utama.

De Porter, Bobbi, \& Hernacki, Mike. (2011). Quantum Learning. Terjemahan Alwiyah Abdurrahman. Bandung: Kaifa.

Handayani, Mimi. (2014). Pengaruh Model Pembelajaran Kooperatif Tipe Two Stay Two Stray Terhadap Pemahaman Konsep MAtematis Siswa. Jurnal Pendidikan Matematika, 3(1), 56-60. 
Hobri. (2009). Model-model Pembelajaran Inovatif. Jember: Center For Society Studies (CSS).

Imaduddin \& Utomo. (2012). Efektifitas Metode Mind mapping Untuk Meningkatkan Prestasi Belajar Fisika Pada Siswa Kelas VIII. Jurnal Humanitas, 9(1), 62-75.

Indriyani, Ria Dwi. (2010). Penerapan Strategi Pembelajaran Mind Mapping dalam Pembelajaran Matematika sebagai Upaya Peningkatan Pemahaman Konsep Teorema Pythagoras. Skripsi tidak diterbitkan. Surakarta: Universitas Muhammadiyah Surakarta.

Lestari, Karunia Eka. (2015). Penerapan Model Pembelajaran M-Apos Untuk Meningkatkan Kemampuan Pemecahan Masalah Matematis Siswa SMP. Jurnal Pendidikan UNSIKA, 3(1), 45-52.

Putra, ED Dan Amalia, R. (2019). Deskripsi Kemampuan Komunikasi Matematis Siswa Dalam Pembelajaran Matematika Nalaria Realistik. Jurnal Dimensi Pendidikan dan Pembelajaran, 7(2), 61-73.

Rianto, Milan. (2006). Pendekatan, Strategi, dan Metode Pembelajaran. Departemen Pendidikan Nasional. Direktorat Jenderal Peningkatan Mutu Pendidik dan Tenaga Kependidikan, Pusat Pengembangan Penataran Guru IPS dan PMP Malang.

Suprijono, Agus. (2009). Cooperative Learning (Teori dan Aplikasi PAIKEM). Yogyakarta: Pustaka Pelajar.

Susanto, H B. (2011). Peningkatan Hasil Belajar IPA dengan Menggunakan Teknik Mind Mapping (Peta Pikiran) pada Materi Fungsi Alat Tubuh Manusia Siswa Kelas IV Semester Ganjil SDN Penataan Winongan Pasuruan Tahun Ajaran 2011/2012. Skripsi tidak diterbitkan. Jember: Universitas Jember. 